\title{
Kalker ve Bazalt Agregaları ile Beton Travers Üretimi
}

\author{
Mehmet KOZAK ${ }^{1}$ \\ 1TCDD 7. Bölge Demiryolu Bakım Servis Müdürlüğü, Afyonkarahisar
}

(Alınış / Received: 23.01.2020, Kabul / Accepted: 01.07.2020)

\author{
Anahtar Kelimeler \\ Travers, \\ Beton travers, \\ Agrega, \\ Kalker, \\ Bazalt
}

\begin{abstract}
Özet: Bu çalışmada, beton travers üretiminde kalker ve bazalt agregasının kullanılabilirliği araştırılmıștır. Çalışmada agrega türü ve maksimum agrega tane boyutu değiştirilerek farklı 6 seri üretilmiştir. Çimento miktarı $450 \mathrm{~kg} / \mathrm{m}^{3}$ ve su/çimento oranı 0.25 olarak sabit tutulmuştur. Her seriden 2 adet beton travers ve 4 adet küp $(20 \times 20 \times 20 \mathrm{~cm})$ üretilerek buhar kürüne tabi tutulmuştur. Üretilen beton traversler üzerinde eğilme dayanımı ve ultrasonic ses geçiş hızı, küp numuneler üzerinde ise 1 ve 28 günlük basınç dayanımı, birim hacim ağırlık, ultrasonic ses geçiş hızı, donma çözünme ve su emme deneyleri yapılmıștır. Bu çalışmada üretilen bütün serilerin, Dywidag normları açısından gerekli dayanımını sağladığı söylenebilir.
\end{abstract}

\section{Concrete Traverse Production With Limestone and Basalt Aggregates}

\section{Keywords}

Sleeper,

Concrete sleeper,

Aggregate,

Limestone,

Basalt

\begin{abstract}
In this study, the usability of limestone and basalt aggregate in concrete sleeper production was investigated. In this study, 6 different series were produced by changing the aggregate type and maximum aggregate grain size. The amount of cement is $450 \mathrm{~kg} / \mathrm{m}^{3}$ and the water / cement ratio is kept constant as 0.25 .2 concrete sleepers and 4 cubes $(20 \times 20 \times 20 \mathrm{~cm})$ were produced from each series and steam cured. Flexural strength and ultrasonic pulse velocity were applied on the concrete sleepers, compressive strength of 1 and 28 days, bulk density, ultrasonic pulse velocity, freeze thaw and water absorption tests were performed on the cubes. It can be said that all series produced in this study provide the necessary resistance in terms of Dywidag norms.
\end{abstract}

\section{Giriş}

Ulaştırma: Eşyanın veya insanın bir yerden başka bir yere taşınması olarak tanımlanmakla birlikte; ulaştırma için malların marjinal faydalarının nispi olarak düşük olduğu yerlerden, daha yüksek olduğu yerlere taşınarak, yer ve zaman faydası meydana getiren bir süreç olarak da tanımlanabilmektedir [1].

Ülke genelinde kolay, hızlı güvenilir ve ekonomik bir ulaştırma hizmeti sağlanabilmesi için; karayolu, demiryolu, denizyolu ve havayolu gibi ulaştırma türlerine ait altyapı tesisleri ile ülke koşullarına uygun düşen bir bütünlük göstermesi ve bu türlerin işletmelerinde koordinasyonunun olması gereklidir [2].
Karayolu yoğun tașımacıllğının sebep olduğu, kazalar, çevre kirliliği, yüksek yakıt maliyetleri ve trafik tıkanıklığı, dünya ekonomisinin gelişmesinde en önemli unsur olan ulaşımı sinırlamakta ve yavaşlatmaktadır. $\mathrm{Bu}$ nedenle Dünya genelinde, demiryollarının önemi her geçen gün daha da artmakta ve demiryolları, son yıllarda ülkemizde de olmak üzere dünya ülkelerinde her yönüyle yeniden yapılandırılmaktadır [3].

Ulaştırma sistemlerinde; konfor, güvenlik, zaman ve güvenirlilik önemli parametrelerdir. Demiryollarını diğer ulaştırma sistemleriyle rekabet edebilir hale getirmek için yukarıda sıralanan parametreleri en az maliyetlerde sağlamak gerekir. Gelişen teknoloji ile 
birlikte, insanların zaman değerinin artması, ulaștırma sistemlerini daha da hızlı olmaya zorlamaktadır. Günümüzde modern demiryolu araçları çok yüksek hızlar yapabilmektedirler. Ancak bu modern demiryolu araçları kullanılmadan önce, demiryolu üstyapısının bu araçları güvenle taşıyacak etkinliğe getirilmesi gerekmektedir [4].

Demiryolu üstyapı ve altyapı olarak iki ana bölümden oluşmaktadır [5]. Demiryolu güzergâhının geçtiği doğal arazi üzerinde; yolun yapımı ve korunması için imal edilen tesislerin tümüne altyapı denilmektedir [6].

Demiryolu araçlarının emniyetli, konforlu ve istenilen hızlarda hareket edebilmesini sağlamak amacıyla belirli kriterler esas alınarak inşa edilen ve demiryolu araçlarının yol ile temasının gerçekleştiği, ray, travers, balast ve bağlantı malzemelerinin tamamına üstyapı denilmektedir [7].

\section{Demiryolu Traversleri}

Rayın altına dik olarak ve belli aralıklarla döșen en yol üst yapı malzemesine travers denilmektedir. Rayların sabit kalmasını sağlamak, raydan gelen yükleri balasta aktarmak ve yol geometrisini korumak gibi görevleri bulunmaktadır. Traversler kullanıldıkları ray tiplerine göre çok değişik tip ve ölçülerde üretilmektedir.

İmal edildikleri malzeme türlerine göre traversler; plastik, ahşap, beton ve demir olmak üzere olmak üzere dörde ayrılmaktadır [8]. TCDD konvansiyonel ana hatlarında kullanılan traverslerin yıllara göre kullanım yüzdeleri Tablo 1.'de verilmiştir.

Tablo 1. TCDD konvansiyonel ana hatlarında kullanılan traverslerin yıllara göre yüzdeleri [9].

\begin{tabular}{cccccc}
\hline \multirow{2}{*}{$\begin{array}{c}\text { Travers } \\
\text { Çeșitleri }\end{array}$} & 2003 & 2006 & 2009 & 2012 & 2016 \\
\cline { 2 - 6 } & 13.28 & 11.7 & 7.8 & 1.6 & 0.8 \\
\hline Demir & 23.74 & 20.0 & 18.9 & 12.4 & 4.3 \\
Ahşap & 23.9 & 64.9 \\
Beton & 62.98 & 68.3 & 73.2 & 86 & 94.9 \\
\hline
\end{tabular}

\subsection{Ahşap traversler}

Ahşap travers imalatında kullanılacak ağaçlar; budaksız ve doğrusal olmalı, çürük ve çatlak olmamalı ayrıca dayanıklılığı için basınçla verilecek kimyasal maddeyi emme yeteneği olmalıdır.

Ahşap traversler, kullanım amacına göre değişik ölçülerde imal edilebilmektedir. İmalat aşamasında dış etkenlere karşı dayanıklılığının artması için ahşap traverslere yüksek basınçta bir petrol türevi olan kreozot maddesi emdirilir. Enjeksiyon adı verilen bu işlem sonucunda, kreozot ahşap traverslerin yüzeyinden itibaren 25 ila $40 \mathrm{~mm}$ derinliğe kadar nüfuz eder. Böylece traverse kimyasal koruma sağlanmıș olmaktadır.

\subsection{Plastik traversler}

Ahşap traverse alternatif olarak ortaya çlkan bir travers çeşididir. Köprüler, makaslar ve normal yollar için üretilen tipleri mevcuttur. Kalıp içerisine erimiş plastik dökülmesi suretiyle imal edilirler.

Gerek yapılan testlerden başarılı sonuçlar alınması, gerekse yakın gelecekte ahşap traverste koruyucu olarak kullanılan kreozotun AB ülkelerinde tamamen yasaklanacak olması, plastik traverslerin ahşap traverse alternatif olarak daha yaygın kullanılacağının bir göstergesidir.

\subsection{Demir traversler}

Demir traversler hangi tip ray için üretilmişler ise sadece o tip ray ile kullanılabilirler. Bunun sonucu olarak ta çok fazla sayıda demir travers tipi mevcuttur. İstisnai olarak; geniş tabanlı bir ray için üretilen bir demir travers, daha dar tabanlı bir ray ile bağlantı malzemelerinde çeșitli kombinasyonlar yapılarak kullanılabilmektedir. Ancak bu durum pek sağlıklı olmadığından zaruri haller dışında tavsiye edilmemektedir.

\subsection{Beton traversler}

Kisaca beton travers olarak tabir edilen betonarme traversler, imalat şekline göre monoblok travers ve ikiz blok travers olmak üzere ikiye ayrılır.

\subsection{1 İkiz blok traversler}

Raylara mesnet teşkil eden iki adet betonarme blok ve bunları birleştiren çelik çubuklardan mamul beton travers çeşididir.

- Kırılma ve çatlamalara karşı dayanıklı değildir.

- Parçalı yapısı nedeniyle gerilmeli olarak imal edilemez.

- Yüzey alanı fazla olduğu için yanal direnimi çok iyidir.

- Maliyeti monoblok traverse göre daha yüksektir.

\subsubsection{Monoblok traversler}

Tek parça olarak ve içinde bulunan çelik gergi çubuklarının gerilmesi suretiyle imal edilen betonarme travers çeșididir.

- İkiz blok traverse göre yanal direnimi daha azdır.

- Kırılma ve çatlamalara karşı daha dayanıklıdır.

- Maliyeti ikiz blok traverse göre daha düșüktür.

- Ön veya son germeli olarak imal edilebilir.

- TCDD şebekesinde bu travers türü kullanılmaktadır. 
Beton traverse esneklik kazandırmak amacıyla ray tabanının altına isabet eden bölgede plastik seletler veya daha kalın lastikten mamul elastik pedler kullanılmaktadır. Son yıllarda makaslarda da beton travers kullanımına geçilmiştir. Beton traversler, birlikte kullanılacağı rayın tipine göre değişik ölçülerde ve ağırlıklarda imal edilir. TCDD şebekesinde B55, B58 ve B70 beton traversler kullanılmaktadır [10]. Son yıllarda 60E1 raylarının kullanımı ile B70 beton traverslerin kullanımı yaygınlaşmıştır.

\section{Materyal ve Metot}

\subsection{Kullanılan malzemeler}

Karışımında çimento, agrega (bazalt ve kalker) ve şebeke suyu kullanılmıştır. Her seri için su/çimento oranı 0.25 ve çimento dozajı ise $450 \mathrm{~kg} / \mathrm{m}^{3}$ olarak sabit tutulmuştur. Agrega ve kum oranları ise ön deneme çalışmalarından elde edilen verilen doğrultusunda belirlenmiştir. Beton karışımında kimyasal madde kullanılmamış olup kullanılan çimento, bazalt ve kalker agregası hakkında kısaca bilgi verilmiştir.

\subsection{1 Çimento}

TS EN 197-1 CEM I 42,5R portland çimentosu kullanılmıştır [11]. 10 gün dinlendirilmiş halde ve dökme çimento şeklinde sıcaklığı en fazla $55^{\circ} \mathrm{C}$ olarak teslim alınmakta olan çimento silolarında çevre koşullarından etkilenmeden korunmaktadır [12].

\subsubsection{Bazalt agregası}

Yerküresinde birçok yerde bulunan ağır, koyu renkli bir kayaçtır. Piroksen ve bazik plajıyoklaslardan oluşmuştur. Fakat o kadar ince dokuludur ki bu mineralleri gözle görmek oldukça zordur. Ayrıca kayaç mineralojik bileşiminde olivin de içerebilir. Genel olarak kayaç yarı yarıya koyu renkli (mafik) mineraller ve feldspattan oluşmuştur. Kayacın rengi koyu gri ile yeşilimsi siyah arasında değişir [13]. Bazalt piroksen ve olivin kristalleri ihtiva eden bir kayaç türüdür [14].

Agrega deneylerinden elde edilen sonuçları doğrultusunda bazalt agregasının elek analizi, beton karıșımında kullanılan karışım oranları ve fiziksel özellikleri Tablo 2.'de verilmektedir.

Tablo 2. Bazalt agregasının elek analizi, beton karıșımında kullanılan karıșım oranları ve fiziksel özellikleri.

\begin{tabular}{|c|c|c|c|c|c|c|c|c|}
\hline \multirow{3}{*}{ Fiziksel Özellikleri } & & \multirow{2}{*}{\multicolumn{4}{|c|}{ Bazalt Agregasının Deney Sonuçları }} & \multicolumn{3}{|c|}{ Kum, Agrega Sınır Değeri [15; 16] } \\
\hline & & & & & & \multirow{2}{*}{$\begin{array}{c}\text { Kum } \\
(0-8 \mathrm{~mm})\end{array}$} & \multirow{2}{*}{$\begin{array}{c}\text { Agrega }(8-16 \\
\text { ve } 16-32 \mathrm{~mm})\end{array}$} & \multirow[t]{2}{*}{ Standart } \\
\hline & & $16-31.5$ & $16-22$ & $8-16$ & $0-8$ & & & \\
\hline \multirow{2}{*}{ Birim Hacim Ağırlık $\left[\mathrm{kg} / \mathrm{m}^{3}\right]$} & Gevşek & 1427 & 1438 & 1449 & 1580 & - & - & - \\
\hline & Sıkışık & 1555 & 1565 & 1576 & 1801 & - & - & - \\
\hline \multicolumn{2}{|l|}{ Özgül Ağırlık [kg/m³] } & 2815 & 2858 & 2981 & 2711 & $\geq 2400$ & $\geq 2600$ & EN 1097-6 \\
\hline \multicolumn{2}{|l|}{ Zararlı Bileșen Miktarı [\%] } & 0 & 0 & 0 & 0 & $\leq \% 0,5$ & $\leq \% 0,5$ & TS 3528 \\
\hline \multicolumn{2}{|l|}{ Kompasite Değeri } & 0,5 & 0,5 & 0,48 & 0,58 & - & - & - \\
\hline \multicolumn{2}{|l|}{ Su Emme [\%] (24 Saat) } & 1,4 & 1,49 & 1,6 & 2,0 & $\leq \% 3$ & $\leq \% 3$ & EN 1097-6 \\
\hline \multicolumn{2}{|l|}{ Aşınma Deneyi [\%] (500 Devir) } & \multicolumn{2}{|c|}{17,5} & \multicolumn{2}{|c|}{-} & $\leq \% 25$ & $\leq \% 22$ & EN 1097-2 \\
\hline \multicolumn{2}{|l|}{ Organik Madde Miktarı } & - & - & - & Açık Sarı & - & - & - \\
\hline \multirow{2}{*}{ Çamurlu Madde Miktarı [\%] } & Ağırlıkça & - & - & - & 2,9 & - & - & - \\
\hline & Hacimce & - & - & - & 4,6 & $\leq \% 3$ & $\leq \% 1$ & TS 3527 \\
\hline \multirow{9}{*}{ Elek Analizi } & 31.5 & 100 & 100 & 100 & 100 & - & - & - \\
\hline & 22 & 48,7 & 100 & 100 & 100 & - & - & - \\
\hline & 16 & 7,5 & 7,5 & 99,4 & 100 & - & - & - \\
\hline & 8 & 0 & 0 & 0,5 & 99,6 & - & - & - \\
\hline & 4 & 0 & 0 & 0 & 81,6 & - & - & - \\
\hline & 2 & 0 & 0 & 0 & 53,6 & - & - & - \\
\hline & 1 & 0 & 0 & 0 & 31,2 & - & - & - \\
\hline & 0.5 & 0 & 0 & 0 & 20,8 & - & - & - \\
\hline & 0.25 & 0 & 0 & 0 & 9,6 & - & - & - \\
\hline \multirow{3}{*}{$\begin{array}{l}\text { Maksimum Agrega Tane } \\
\text { Boyutuna Göre Karışım Oranı [\%] }\end{array}$} & 31.5 & 39,47 & - & 13,16 & 47,37 & - & - & - \\
\hline & 22 & - & 39,47 & 13,16 & 47,37 & - & - & - \\
\hline & 16 & - & - & 40 & 60 & - & - & - \\
\hline
\end{tabular}

\subsubsection{Kalker agregası}

Kimyasal bileşiminde en az \% 90 kalsiyum karbonat $\left(\mathrm{CaCO}_{3}\right)$ içeren kayaçlara kalker ya da kireçtaşı adı verilmektedir. Ayrica mineralojik bileşiminde en az \%
90 kalsit minerali bulunan kayaçlar da kalker olarak adlandırılmaktadır [17].

Agrega deneylerinden elde edilen sonuçları doğrultusunda kalker agregasının elek analizi, beton karıșımında kullanılan karışım oranları ve fiziksel özellikleri Tablo 3.'de verilmektedir. 
Tablo 3. Kalker agregasının elek analizi, beton karıșımında kullanılan karıșım oranları ve fiziksel özellikleri.

\begin{tabular}{|c|c|c|c|c|c|c|c|c|}
\hline \multirow{2}{*}{\multicolumn{2}{|c|}{ Fiziksel Özellikleri }} & \multirow{2}{*}{\multicolumn{4}{|c|}{ Kalker Agregasının Deney Sonuçları }} & \multicolumn{3}{|c|}{ Kum, Agrega Sınır Değeri $[15 ; 16]$} \\
\hline & & & & & & \multirow{2}{*}{$\begin{array}{c}\text { Kum } \\
(0-8 \mathrm{~mm})\end{array}$} & \multirow{2}{*}{$\begin{array}{l}\text { Agrega }(8-16 \\
\text { ve } 16-32 \mathrm{~mm})\end{array}$} & \multirow[t]{2}{*}{ Standart } \\
\hline & & $16-31.5$ & $16-22$ & $8-16$ & $0-8$ & & & \\
\hline \multirow{2}{*}{ Birim Hacim Ağırlık $\left[\mathrm{kg} / \mathrm{m}^{3}\right]$} & Gevşek & 1400 & 1406 & 1432 & 1664 & - & - & - \\
\hline & Sıkışık & 1557 & 1564 & 1580 & 1904 & - & - & - \\
\hline \multicolumn{2}{|l|}{ Özgül Ağırlık [kg/m³] } & 2722 & 2738 & 2760 & 2610 & $\geq 2400$ & $\geq 2600$ & EN 1097-6 \\
\hline \multicolumn{2}{|l|}{ Zararlı Bileșen Miktarı [\%] } & 0 & 0 & 0 & 0 & $\leq \% 0,5$ & $\leq \% 0,5$ & TS 3528 \\
\hline \multicolumn{2}{|l|}{ Kompasite Değeri } & 0,51 & 0,51 & 0,51 & 0,63 & - & - & - \\
\hline \multicolumn{2}{|l|}{$\begin{array}{l}\text { Su Emme [\%] (24 Saat) } \\
\text { Asuma Denevi [\%] } 500 \text { Devir) }\end{array}$} & 0,7 & 0,78 & 0,95 & 1,08 & $\leq \% 3$ & $\leq \% 3$ & EN 1097-6 \\
\hline Așınma Deneyi [\%] (500 Devir) & & \multicolumn{2}{|c|}{22,00} & \multicolumn{2}{|c|}{-} & $\leq \% 25$ & $\leq \% 22$ & EN $1097-2$ \\
\hline Organik Madde Miktarı & & - & - & - & Renksiz & - & - & - \\
\hline \multirow{2}{*}{ Çamurlu Madde Miktarı [\%] } & Ağırlıkça & - & - & - & 2,7 & - & - & - \\
\hline & Hacimce & - & - & - & 4,5 & $\leq \% 3$ & $\leq \% 1$ & TS 3527 \\
\hline \multirow{9}{*}{ Elek Analizi } & 31.5 & 100 & 100 & 100 & 100 & - & - & - \\
\hline & 22 & 87,3 & 100 & 100 & 100 & - & - & - \\
\hline & 16 & 65 & 65 & 97 & 99 & - & - & - \\
\hline & 8 & 2 & 2 & 13 & 75 & - & - & - \\
\hline & 4 & 0 & 0 & 7 & 62 & - & - & - \\
\hline & 2 & 0 & 0 & 6 & 41 & - & - & - \\
\hline & 1 & 0 & 0 & 5 & 23 & - & - & - \\
\hline & 0.5 & 0 & 0 & 4 & 16 & - & - & - \\
\hline & 0.25 & 0 & 0 & 3 & 8 & - & - & - \\
\hline \multirow{3}{*}{$\begin{array}{l}\text { Maksimum Agrega Tane } \\
\text { Boyutuna Göre Karıșım Oranı [\%] }\end{array}$} & 31.5 & 34 & - & 17 & 49 & - & - & - \\
\hline & 22 & - & 34 & 17 & 49 & - & - & - \\
\hline & 16 & - & - & 30 & 70 & - & - & - \\
\hline
\end{tabular}

\subsection{Numunelerin üretilmesi,}

Çalışmada kalker ve bazalt agregaları kullanılarak en büyük tane çapları $16 \mathrm{~mm}, 22 \mathrm{~mm}$ ve $31,6 \mathrm{~mm}$ olmak üzere altı farklı seri üretilmiştir. Bu seriler çalışmada Tablo 4.'deki gibi isimlendirilmiștir.

Tablo 4. Üretilen serilerin isimlendirilmesi.

\begin{tabular}{c|ccc}
\hline Agrega & \multicolumn{3}{|c}{ Maksimum } \\
\cline { 2 - 4 } Çeşidi & 16 & 22 & 31.5 \\
\hline Bazalt & B16 & B22 & B32 \\
Kalker & K16 & K22 & K32 \\
\hline
\end{tabular}

Her bir seriden; 2 adet tek bloklu B58 beton travers ve 4 adet küp numune üretilmiştir. Üretilen numuneler buhar kürü için istife alınmış ve bir istifin tamamlanması doksan dakika sürmüş ve istif tamamlanır tamamlanmaz, istifin üzerine kür çadırı yerleştirilmiştir. Buhar kürü Dywidag normlarına göre uygulanmış ve kür çadırı içerisindeki sıcaklık Şekil 1.'de verildiği gibi kademeler şeklinde yükseltilerek uygulanmıștır.

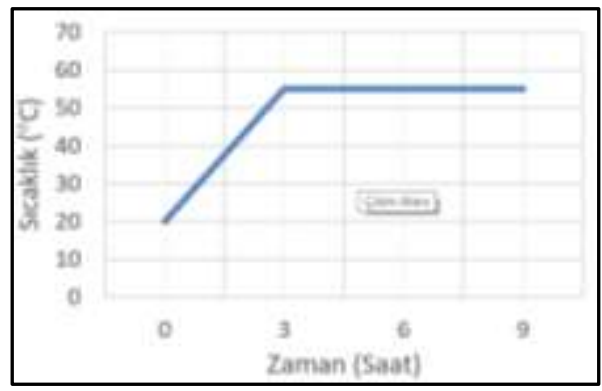

Şekil 1. Buhar kürü sıcaklık zaman grafiği.
Buhar küründen sonra numuneler oda sıcaklığında 13.5 saat soğuması için bekletilmektedir. Dywidag normlarına göre beton traverslerin sonradan germe tekniğine göre germe işlemleri tamamlanmıştır [18].

\section{Bulgular}

\subsection{Birim hacim ağırlık}

Üretilen küp numuneler üzerinde yapılan birim hacim ağırlık deneyi sonucunda elde edilen veriler Șekil 2.'de sunulmuştur.

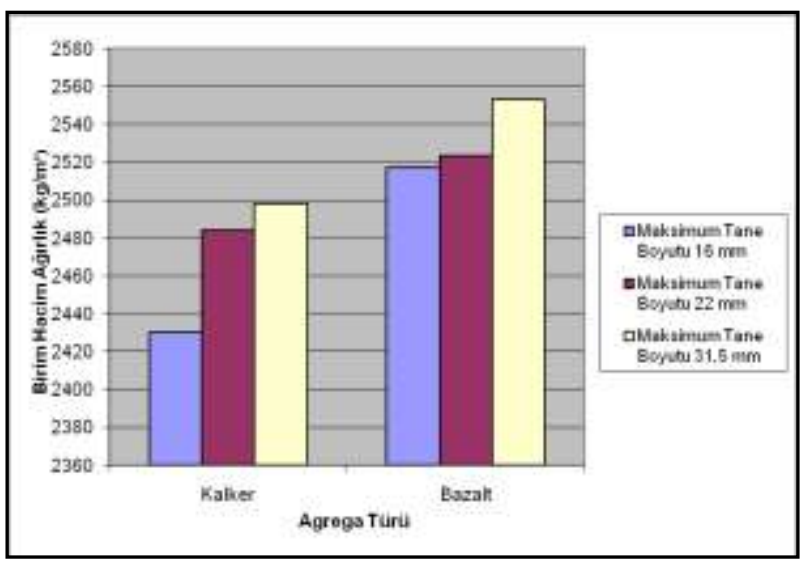

Şekil 2. Küp numunelerin birim hacim ağırlıkları.

Birim hacim ağırlık, beton karıșımında kullanılan agrega türüne göre değerlendirildiğinde, bazalt agregası ile üretilen betonun, kalker agregası ile üretilen betondan birim hacim ağırlığının daha yüksek olduğu gözlenmiş ve bunun nedenin ise bazalt 
agregası özgül ağırlığının, daha yüksek olduğundan dolayı meydana geldiği düșünülmektedir.

\subsection{Basınç dayanımı}

Üretilen küp numuneler üzerinde yapılan 1 günlük basınç deneyi sonucunda elde edilen veriler Şekil 3.'de sunulmuştur.

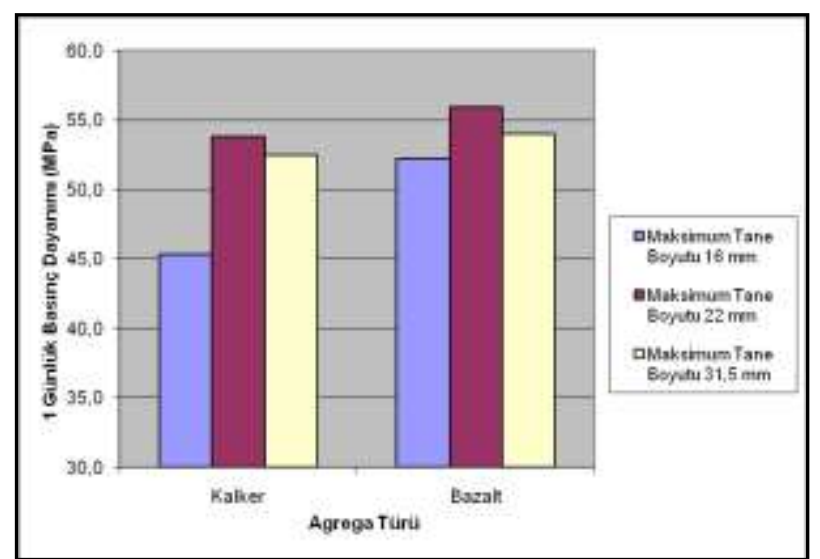

Şekil 3. Küp numunelerin 1 günlük basınç dayanımları.

Dywidag normları açısından, küp numunelerin 1 günlük basınç dayanımının en az $48 \mathrm{MPa}$ olması gerekmektedir [18]. Bu çalışma da üretilen küp numunelerden ise sadece K16 serisinin 1 günlük basınç mukavemetleri 48 MPa'dan az geldiği gözlenmiş diğer serilerde ise istenen dayanımı sağlamıştır.

Agrega türü açısından 1 günlük basınç dayanımı değerlendirildiğinde bazalt agregası kullanılarak üretilen numunelerin basınç dayanımları kalker agregası ile üretilen numunelere göre daha yüksek olduğu gözlenmiș ve bunun nedeninin ise bazalt agregasının aşınma değerinin daha düşük olmasının yanı sıra çimento bağlayıcısı ile daha iyi aderans sağlamasına bağlanabilir.

Üretilen küp numuneler üzerinde yapılan 28 günlük basınç deneyi sonucunda elde edilen veriler Şekil 4.'de sunulmuştur.

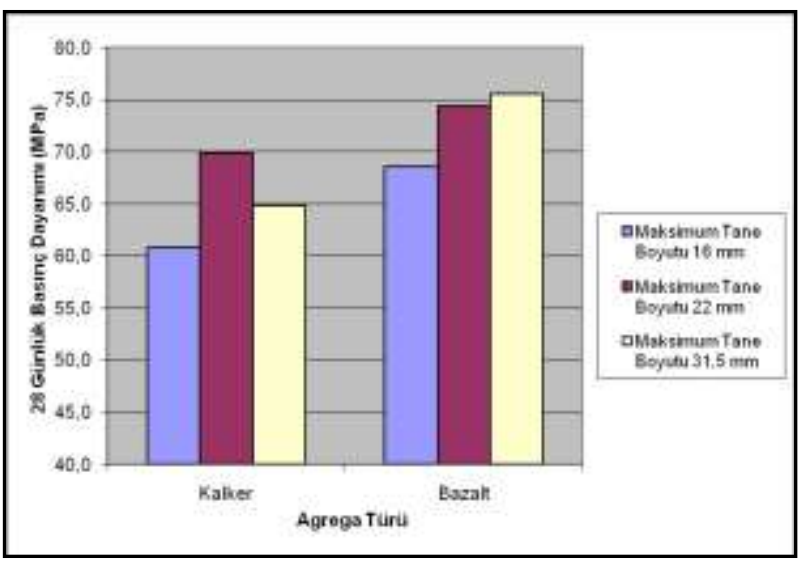

Şekil 4. Küp numunelerin 28 günlük basınç dayanımları.
Dywidag normları açısından, küp numunelerin 28 günlük basınç dayanımının en az $60 \mathrm{MPa}$ olması gerekmektedir [18]. 1 günlük basınç dayanımı Dywidag normlarına göre 48 MPa'dan az gelen K16 serisinin 28 günlük basınç mukavemeti ise $60 \mathrm{MPa} n ı n$ üstünde elde edilmiştir. Yani zamana göre basınç dayanım da artış görülmüştür.

Agrega türünün basınç dayanımı üzerine etkisi incelendiğinde 1 günlük numunelerde olduğu gibi 28 günlük basınç dayanımı değerlerinde de bazalt agregalarının etkisi kalker agregalı betonlara göre daha yüksek çıktığı görülmüștür. Bu durum bazalt agregasının dayanımının ve özgül ağırlığının kalker agregasına göre daha yüksek olmasından dolayı olduğu söylenebilir.

Bazalt agregaları daha düşük aşınma kaybına sahip olmakla birlikte kireçtaşına göre daha fazla su emme değerine sahiptir, bu da bazalt agregalarının kireçtaşına göre daha gözenekli agregalar olduğunu göstermektedir. Gözeneklerde bulunan serbest su çimentonun hidratasyonu sırasında kullanılmış olup, agrega gözeneklerinde de çimento hidrate ürünleri gelişmiştir. Böylece bazalt agregalarının kullanılmasıyla, çimento hamuru agrega ara yüzeyindeki kenetlenme veya aderans derecesi kireç taşıyla üretilen betonlara göre çok daha yüksek olduğu düşünülmekte ve bu sayede ileriki yaşlardaki basınç dayanımı değeri de kenetlenmenin daha iyi olmasından dolayı bazalt agregasının kullanıldığı serilerde daha fazla görülmüştür.

\subsection{Ultrases hızı}

Üretilen küp numuneler üzerinde yapılan ultrases geçiş hızı deneyi sonucunda elde edilen veriler Şekil 5.'de sunulmuştur.

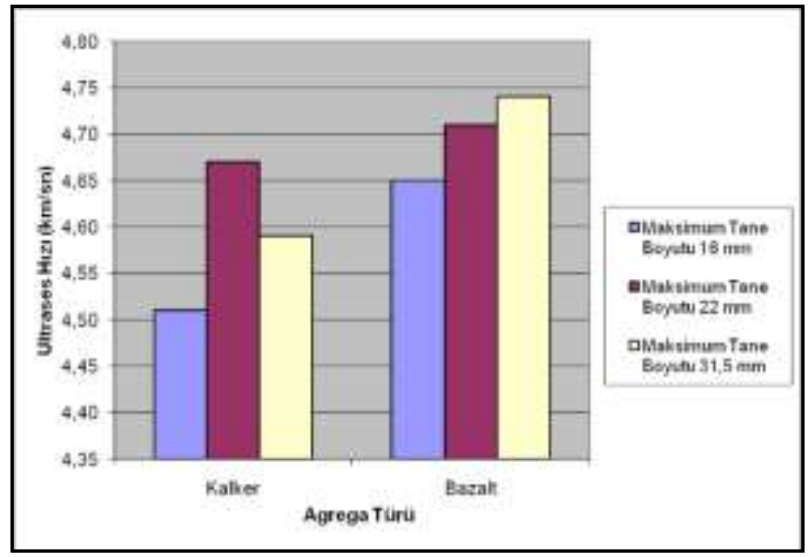

Şekil 5. Küp numunelerin ultrases hızı.

Üretilen B58 beton travers numuneler üzerinde yapılan ultrases geçiş hızı deneyi sonucunda elde edilen veriler Șekil 6.'de sunulmuștur. 


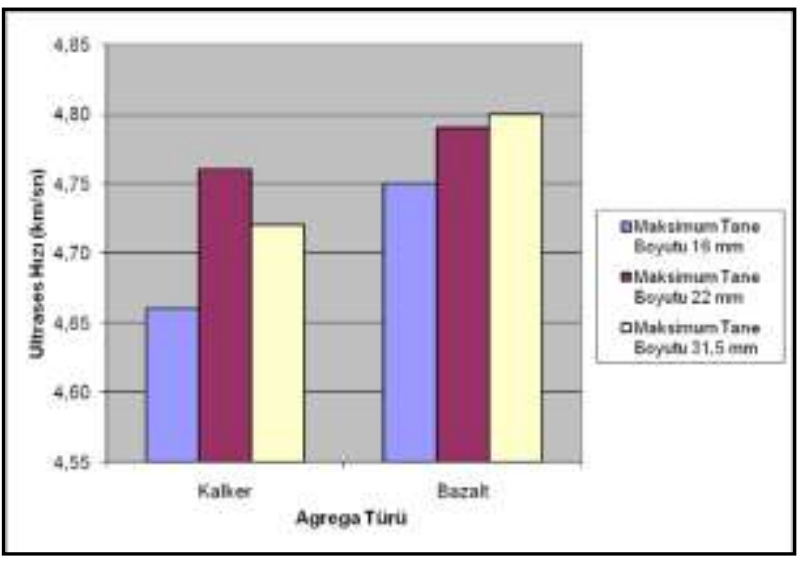

Şekil 6. B58 beton traverslerin ultrases hızı.

Literatür çalışmalarından bilindiği gibi basınç dayanımı ile ultrases hızı arasında doğru orantı bulunmaktadır. Bu çalışmada da bu doğru orantı gözlenmiştir.

\subsection{B58 beton traverslerde eğilme dayanımı}

Çalışmada kalker ve bazalt agregaları kullanılarak üretilen serilere ait tek bloklu B58 beton traversler üzerinde eğilme deneyi yapılmıștır. Beton traversler üzerinde eğilme deneyi traverslerin orta noktasına tekil bir yük uygulanarak yapılarak formül (1) yardımıyla eğilme dayanımları hesaplanmıștır.

$$
f_{c f}=\frac{3 F L}{2 d_{1} d_{2}^{2}}
$$

Üretilen B58 beton travers numuneler üzerinde yapılan eğilme deneyi sonucunda elde edilen veriler Şekil 7.'de sunulmuştur.

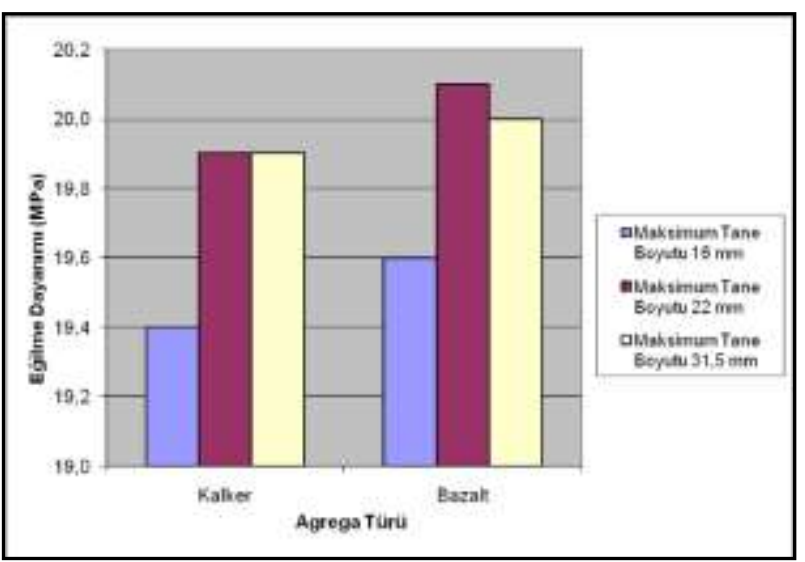

Şekil 7. B58 beton travers eğilme dayanımları.

Deney sonuçları kullanılan agrega türü açısından değerlendirildiğinde; bazalt agregası ile üretilen beton traverslerin eğilme dayanımının, kalker agregası ile üretilen beton traverslerin eğilme dayanımından daha yüksek geldiği gözlenmiştir.

Çalışmada kullanılan en düşük eğilme dayanımının, agrega maksimum tane boyutu açısından K16 ve B16 serilerinde olduğu gözlenmiştir.
Dywidag normları açısından, traverslerin 1 dakika süresince $45000 \mathrm{~N}$ yük altında çatlama gerçekleşmemesi istenmektedir [18].

Üretilen B58 beton traverslerde 1 dakika süresince $45000 \mathrm{~N}$ yük uygulanmıs ve herhangi bir çatlama gözlenmemiştir. En düşük eğilme dayanımı K16 serisinde gözlenmiş ve bu seride çatlama $75350 \mathrm{~N}$ yükte meydana geldiği gözlenmiștir.

\subsection{Donma çözünme deney sonuçları}

Donma çözünme deneyi TS 3449 göre yapılmış ve her bir çevrim 1 saat $-20{ }^{\circ} \mathrm{C}$ donma, 2 saat $+20{ }^{\circ} \mathrm{C}$ 'de çözünmeden oluşmaktadır. Donma çözünme deneyi 30 çevrim donma - çözülme şeklinde uygulanmıştır. Küp numuneler üzerinde yapılan donma çözünme deney sonuçları Çizelge 5.'de verilmiştir.

Tablo 5: Donma-çözünme deney sonuçları.

\begin{tabular}{c|ccc}
\hline \multirow{2}{*}{$\begin{array}{c}\text { Seri } \\
\text { Isimleri }\end{array}$} & \multicolumn{3}{|c}{ Meydana Gelen Kayılar (\%) } \\
\cline { 2 - 4 } & Ağırlı & Ultrases & Basınç \\
\hline B32 & 0.04 & 4.12 & 3.5 \\
B22 & 0.05 & 4.75 & 3.7 \\
B16 & 0.07 & 5.30 & 4.0 \\
K32 & 0.03 & 4.90 & 3.9 \\
K22 & 0.04 & 5.37 & 4.0 \\
K16 & 0.05 & 5.94 & 4.5 \\
\hline
\end{tabular}

Maksimum agrega tane boyutu azaldıkça kütle, basınç ve ultrases hız kayıpları artış göstermiştir. Bazalt agregası kullanılan numunelerde, kalker agregası kullanılan numunelere göre daha fazla kütle kaybı gerçekleşmiştir. Bunun sebebi olarak da bazalt agregasının su emme oranının daha yüksek olmasının olduğu düșünülmektedir.

Basınç mukavemeti kaybı agrega maksimum tane boyutu ile ters orantılı olduğu gözlenmiștir. Bazalt agregasında daha az basınç mukavemeti kaybı gerçekleșmiş ve bunun sebebi olarak da bazalt agregasının aşınma değerinin daha düşük olmasının olduğu düşünülmektedir.

\section{Sonuçlar ve Öneriler}

1 ve 28 günlük basınç dayanımı agrega türüne göre karşılaştırıldığında bazalt agregası kullanılan küplerin, kalker agregasına göre basınç dayanımlarının daha yüksek geldiği sonucuna ulaşılmıștır. Bunun yanında bazalt ve kalker agregaları ile üretilen numunelerin basınç dayanımlarının (K16 serisinin 1 günlük basınç dayanımı hariç) Dywidag normları açısından istenilen sınır değerleri sağlamadığı sonucuna ulaşılmıştır.

Bazalt ve kalker agregalarından üretilen numunelerin basınç dayanımı, maksimum agrega tane boyutu 16 
mm olarak üretilen serilerde düşük olduğu, en büyük agrega tane çapı $31,5 \mathrm{~mm}$ ve $22 \mathrm{~mm}$ olarak üretilen serilerde ise agrega türü açısından değerlendirilmediğinde çok fazla bir fark olmamasına rağmen maksimum agrega tane boyutu $22 \mathrm{~mm}$ olarak üretilen numunelerde daha yüksek basınç dayanımlarına ulaşılmıştır.

Donma çözünme deneyi sonucuna, basınç ve ultrases hızı kaybının kalker agregası ile üretilen numunelerde daha fazla olmasının yanında bazalt agregası ile üretilen numunelerde ise kütle kaybının daha fazla olduğu sonucuna ulaşılmış. Bunun nedeni olarak kalker agregasının daha az su emme kapasitesi ile daha yüksek aşınma değerine sahip olması nedeniyle meydana geldiği düşünülmektedir.

Bazalt ve kalker agregaları ile üretilen beton travers numunelerinin eğilme dayanımının Dywidag normları açısından istenilen değerleri sağladığı gözlenmiştir.

Üretilen seriler arasında bazalt agregası ile üretilen numunelerin kalker agregası ile üretilen numunelere göre basınç ve eğilme dayanımı açısından daha iyi sonuçlar verdiği gözlenmiştir. Ayrıca üretilen bütün seriler için 28 günlük basınç dayanımı ve eğilme dayanımının Dywidag normları açısından sağladığı sonucuna ulaşilmıştır.

Kalker agregasında, bazalt agregasına göre alkalisilika reaksiyonun daha az meydana geldiği literatür çalışmaları ile bilinmektedir. Doğal hava şartlarına her zaman maruz kalan beton traverslerin üretiminde kalker agregasının kullanılması ile, beton traverslerde meydana gelen alkali-silika reaksiyonunun daha aza indirileceği düşünülmektedir.

Not: Bu çalışma, 02-04 March 2015 tarihlerinde IcAre'15 International Congress On Advanced Railway Engineering kongresinde sunulmuștur.

\section{Kaynakça}

[1] Altınok, S., 2001. Türkiye'de Ulaştırma Politikaları, Karayolları ve Demiryollarının Mukayesesi. Sosyal Ekonomik Araştırmalar Dergisi, 1(1-2), 72-87.

[2] Yayla, N., 2004. Karayolu Mühendisliği. Birsen Yayınevi, İstanbul.

[3] Kozak, M., 2010. Beton Travers Üretiminde Agrega Türü (Bazalt - Kalker) ve Çelik Lifin Kullanılabilirliğinin Araştırılması. Yüksek Lisans Tezi, Afyon Kocatepe Üniversitesi, Fen Bilimleri Enstitüsü, Afyonkarahisar.

[4] Güler, H. ve Jovanovic S. 2005. Demiryollarında Hız Yükseltilmesi Amacıyla Yapılması Gerekli Ön Çalışmalar. 6. Ulaştırma Kongresi, 275-286, İstanbul, Türkiye, 23-25 Mayıs.
[5] Kozak, M., 2011. Demiryolunda Rayların Birleşim Noktaları ve Özelliklerinin Araștırılması. Yapı Teknolojileri Elektronik Dergisi, 7(2), 40-49.

[6] Anonim., 2016. Yol Mühendisleri Kursu Yol Altyapısı Ders Notları. TCDD Eğitim ve Öğretim Dairesi Başkanlığı Yayınları, Ankara.

[7] Anonim., 2016. Yol Mühendisleri Kursu Yol Üstyapı Ders Notları. TCDD Eğitim ve Öğretim Dairesi Başkanlığı Yayınları, Ankara.

[8] Özen, M., 2014. Mesleki Yol Bilgisi. Türkiye Cumhuriyeti Devlet Demiryolları İșletmesi Genel Müdürlüğü, İnsan Kaynakları Dairesi Başkanlığı Yayınları, Ankara.

[9] http://www.tcdd.gov.tr/content/35, 15.01.2019

[10] Özen, M., Kılıç, R., Karlıdağ, H., Koçtürk, B., 2018. Yol Yapım, Kontrol, Bakım, Onarım İșlemleri Ders Notları. Türkiye Cumhuriyeti Devlet Demiryolları İşletmesi Genel Müdürlüğü, İnsan Kaynakları Dairesi Başkanlığı Yayınları, Ankara.

[11] Anonim, 2002. TS EN 197-1 Çimento - Bölüm 1: Genel Çimentolar - Bileşim, Özellikler ve Uygunluk Kriterleri. Türk Standardları Enstitüsü, Ankara.

[12] Gürler, M., Yenel, C., Demirkıran, T., Sağlam, B., 2007b. Beton Travers Üretiminde Kullanılan Çimento Teknik Şartnamesi. TCDD İşletmesi Genel Müdürlüğü Yol Dairesi Başkanlığı Travers Şubesi, Ankara.

[13] Uz, B., 2000. Maden-Jeoloji-Jeofizik Mühendisliğinde Petrografi Prensipleri. 3. Baskı, Birsen Yayınevi, İstanbul.

[14] Anonim, 1997. TS 10088 EN 932-3 Agregaların Genel Özellikleri İçin Deneyler Kısım-3: Basitleștirilmiș Petrografik Tanımlama İçin İșlem ve Terminoloji. Türk Standardları Enstitüsü, Ankara.

[15] Gürler, M., Yenel, C., Demirkıran, T., Sağlam, B., 2007. Beton Travers Üretiminde Kullanilan Agrega Teknik Șartnamesi. TCDD İșletmesi Genel Müdürlüğü Yol Dairesi Başkanlığı Travers Şubesi, Ankara.

[16] Gürler, M., Yenel, C., Demirkıran, T., Sağlam, B., 2007. Beton Travers Üretiminde Kullanılan Kum Teknik Şartnamesi. TCDD İşletmesi Genel Müdürlüğü Yol Dairesi Başkanlığı Travers Şubesi, Ankara.

[17] Yüce, E.A., Gürkan, V., Erdoğan, M., Tarkan, Girgin, Ş., Kangal, M.O., Oktay, F.Y., 2002. Demir Çelik Kullanım Amaçlı Kireçtașları İçin Yeni Bir Tanımlama Önerisi. Madencilik, 41(4), 21-36.

[18] Anonim, 1976. Öngerilimli Beton Traverslere Mahsus İmalat Talimatı Ani Kalıptan Çıkarma Usulüne Göre. Dywidag Normları. 